\title{
Application of Telescopic Mesh Refinement to a Regional Model to Simulate Ground-Water Flow in Webberville, Michigan
}

U.S. Geological Survey

Water-Resources Investigations Report 01-4006

Prepared in cooperation with the Tri-County Regional Planning Commission

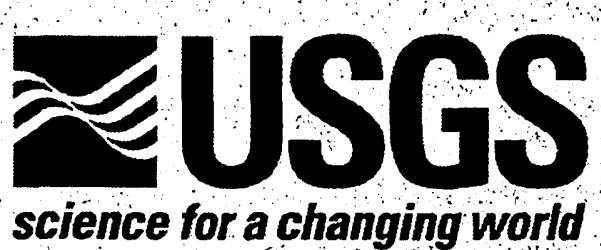




\section{Application of Telescopic Mesh Refinement to a Regional Model to Simulate Ground-Water Flow in Webberville, Michigan}

by Carol L. Luukkonen

U.S. Geological Survey

Water-Resources Investigations Report 01-4006

Lansing, Michigan

2001

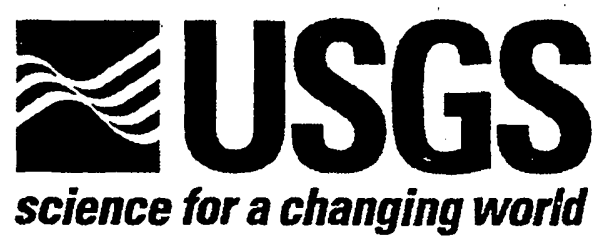




\section{U.S. DEPARTMENT OF THE INTERIOR \\ GALE A. NORTON, Secretary}

U.S. GEOLOGICAL SURVEY

Charles G. Groat, Director

For additional information write to:

Chief, Michigan District

U.S. Geological Survey

Water Resources Division

6520 Mercantile Way, Suite 5

Lansing, MI 48911-6957.
Copies of this report can be purchased from:

U.S. Geological Survey

Branch of Information Services

Box 25286

Denver, CO 80225 


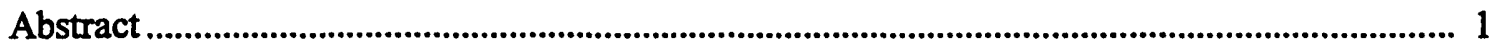

Introduction ................................................................................................................. 1

Purpose and Scope ...................................................................................................... 2

Previous studies........................................................................................................................ 2

Acknowledgments.......................................................................................................... 2

Description of study area and hydrogeologic setting.................................................................. 2

Telescopic mesh refinement.......................................................................................................... 5

Regional model ............................................................................................................. 6

Local model.................................................................................................................. 6

Comparison of regional and local models...................................................................... 8

Delineation of contributing areas .......................................................................................... 8

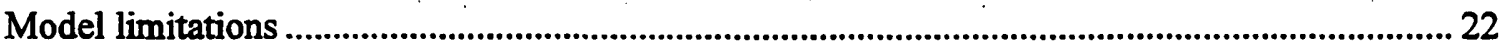

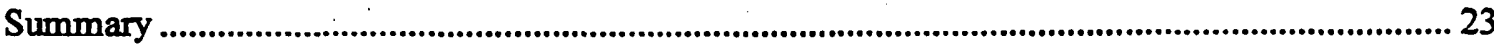

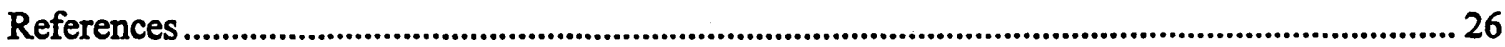

\section{FIGURES}

1-8. Maps showing:

1. Location of Webberville and the Tri-County regional model area in the Lower Peninsula of Michigan.................................................................................................... 3

2. Ground-water levels in the Saginaw aquifer, Webberville, Michigan ...................................... 4

3. Local model of the Webberville area within the Tri-County regional model area, Michigan ................................................................................................................. 7

4. Estimated configuration of the bedrock surface, Webberville .................................................. 10

5. Estimated hydraulic conductivity of the upper aquifer, Webberville......................................... 11

6. Estimated transmissivity of the lower aquifer, Webberville ...................................................... 12

7. Simulated head in the upper aquifer, Webberville ...................................................................... 13

8. Simulated head in the lower aquifer, Webberville ..................................................................... 14

9-15. Maps showing:

9. Distribution of water-level residuals in the Saginaw aquifer, Webberville. 
10. Contributing and zone-of-transport areas for existing wells, Webberville

11. Contributing and zone-of-transport areas for existing and proposed location A wells, Webberville

12. Contributing and zone-of-transport areas for existing and proposed location

B wells, Webberville

13. Contributing and zone-of-transport areas for existing and proposed location C wells, Webberville

14. Contributing and zone-of-transport areas for existing and proposed location $A, B$, and C wells, Webberville.

15. Contributing and zone-of-transport areas for proposed location $A, B$, and $C$ wells, Webberville.

16. Graph showing relation between simulated and observed heads in the Saginaw aquifer, Webberville

17. Map showing extent of 10-year zone of transport areas for existing wells using modified model parameters, Webberville.

\section{TABLES}

1. Approximate location of Webberville's public-supply wells

2. Comparison of Tri-county regional and Webberville local model budgets

3. Contributing and zone-of-transport areas for pumping well scenarios, 


\section{Conversion Factors, Abbreviations, and Vertical Datum}

\begin{tabular}{lll}
\hline Multiply & By & To Obtain \\
\hline inches (in) & 25.4 & millimeters \\
foot (ft) & 0.3048 & meter \\
mile (mi) & 1.609 & kilometer \\
square mile (mi $\left.{ }^{2}\right)$ & 2.590 & square kilometer
\end{tabular}

Hydraulic Conductivity

foot per day (ft/d)

0.1524

meter per day

Transmissivity

Square foot per day $\left(\mathrm{ft}^{2} / \mathrm{d}\right)$

0.09290

square meter per day

Flow

cubic foot per second $\left(\mathrm{ft}^{3} / \mathrm{s}\right)$

0.02832

cubic meter per second

Temperature

Temperature is given in degrees Celsius $\left({ }^{0} \mathrm{C}\right)$, which can be converted to degrees Fahrenheit $\left({ }^{0} \mathrm{~F}\right)$ by the following equation:

${ }^{0} \mathrm{~F}=\left({ }^{0} \mathrm{C}=32\right) \times 1.8$

\section{Vertical Datum}

In this report, "sea level" refers to the National Geodetic Vertical Datum of 1929 (NGVD of 1929) - a geodetic datum derived from a general adjustment of the first-order level nets of the United States and Canada, formerly called Sea Level Datum of 1929. 


\title{
Application of Telescopic Mesh Refinement to a Regional Model to Simulate Ground-Water Flow in Webberville, Michigan
}

\author{
By C.L. Luukkonen
}

\begin{abstract}
Telescopic mesh refinement was applied to a regional ground-water-flow model to create a local model of the Webberville, Michigan area. The local model, with finer grid spacing than the regional model and more detail on local variations in the surface of the Saginaw Formation, the principal aquifer in the area, was used to delineate contributing and zoneof-transport areas to Webberville's existing and proposed additional public-supply wells. Six possible ground-water development scenarios are evaluated to determine the potential effect of the number and location of pumping wells on the shape and extent of the contributing and zone-of-transport areas. Ten-year zone-oftransport, as well as 40-year contributing and zone-of-transport areas, generally consist of disconnected areas near each simulated well.
\end{abstract}

\section{INTRODUCTION}

Ground-water-flow models provide a means to answer questions about a groundwater system of interest, such as the extent and location of contributing areas to pumping wells. Development and calibration of a ground-water-flow model to describe local flow conditions require considerable time and effort, much of which is spent acquiring detailed information about the area of interest. Additionally, boundary conditions that describe flow into and out of the study area must be considered. Simulation of physical boundaries, such as ground-water flow divides, would be ideal in modeling studies; however, physical boundaries to the ground-water flow system might be of regional extent and require collection of much more information than needed for studies describing the local flow system. When a regional model is available, some questions about a local flow system can be answered; however, regional models commonly do not have enough detail in the area of interest to adequately describe local flow conditions. Telescopic mesh refinement provides a means whereby a local model, including simulated characteristics and boundary conditions, is derived from a regional model.

The village of Webberville, in Ingham County, Michigan, is developing a Wellhead Protection Plan (WHPP). This plan describes the community's approaches to protect the quality of ground water withdrawn by their public-supply wells. As part of the WHPP, Webberville needs to delineate the areas that contribute water to their public-supply wells. The village's three public-supply wells withdraw water from the Saginaw aquifer.

The U.S. Geological Survey (USGS), in cooperation with the Tri-County Region Groundwater Management Board, completed an analysis of ground-water resources of the Tri-County region, which includes Clinton, Eaton, and Ingham Counties (Holtschlag and others, 1996). As part of this study, a computer model was developed to describe ground-water flow and the effects of pumping on groundwater levels and directions of ground-water flow in the Saginaw aquifer (fig. 1). This model covers a three-county area; however, the grid spacing is too large to adequately describe contributing areas to Webberville's public-supply wells. Additionally, local studies (C.J. Linck and Associates, 1990, 1991, and 1992) indicate that the bedrock surface in the regional model does not include local trends in the Webberville area. Thus, the USGS, in cooperation with the Tri-County Regional Planning Commission, began a study to 
develop a local model of the Webberville area, using the regional model as a starting point, that could be used to delineate contributing areas to Webberville's public-supply wells.

\section{Purpose and scope}

This report describes the use of a telescopic mesh refinement program, MODTMR (Leake and Claar, 1999), to create a local model of the Webberville area from the regional Tri-County model. The report also describes a comparison of water budgets between the two models, modification of the models to represent local conditions, and the delineation of contributing areas to Webberville's public-supply wells. Particle-tracking analysis was used in conjunction with results of flow simulations to delineate the land surface and subsurface areas that contribute water to the public-supply wells.

\section{Previous studies}

Several studies have contributed to the understanding of the geology and hydrology of this area. C.J. Linck and Associates (1990, 1991, and 1992) have conducted three investigations in the Webberville area - a hydrogeologic investigation of the Webberville area; an aquifer performance test on TW 91-A Summit Street Site; and an evaluation of production at Well No. 3 Summit Street Site. An additional water system reliability study and master plan was conducted by McNamee, Porter and Seeley (1999).

\section{Acknowledgments}

The author gratefully acknowledges the assistance of William Parisian, Public Works Supervisor, and Bryan Armstrong, past village trustee, for providing information and access to the public-supply wells and providing other sources of information about the village. Christine Spitzley, Tri-County Regional Planning Commission, and Brant Fisher, Drinking Water and Radiological Protection Division, Michigan Department of Environmental Quality, were also very helpful for providing information about the requirements for Wellhead Protection Plans and delineation of contributing areas. Special thanks also go to the homeowners who permitted access to their wells for water-level measurements and to Margaret $\mathrm{Li}$ for her assistance collecting these measurements.

\section{DESCRIPTION OF STUDY AREA AND HYDROGEOLOGIC SETTING}

The Village of Webberville lies in the northeastern part of Ingham County in the Lower Peninsula of Michigan (fig. 1). Within the Webberville area, sandstones of the basal member of the Saginaw Formation, generally referred to as the Parma Sandstone, provide most of the water to residential and public-supply wells (C.J. Linck and Associates, 1990). The Saginaw Formation extends to a depth of about 200 feet below land surface and consists of sandstone, shale, coal, and limestone. A depression or valley in the bedrock surface trends generally north-south through the center of the village, apparently reflecting an old drainage pattern prior to glaciation. Within the Parma Sandstone in the Webberville area, the thickness of sandstone ranges from less than $5 \mathrm{ft}$ to more than $80 \mathrm{ft}$; the area of thickest sandstone trends north-south through Webberville (C.J. Linck and Associates, 1990).

Glacial deposits form the uppermost aquifer in the Webberville area. These deposits range in thickness from 35 to $120 \mathrm{ft}$ and consist primarily of sand, gravel, and clay. Where present, deposits of sand and gravel are a source of water; however, because of the relatively shallow depth to bedrock, few domestic wells withdraw water from the glacial deposits (C.J. Linck and Associates, 1990). Areas of thickest sand and gravel deposits follow the same north-south trend as the bedrock valley mentioned previously.

Ground-water level observations indicate that flow is primarily from south to north in the Webberville area (fig. 2). A small cone of depression has developed as a result of municipal pumping (C.J. Linck and Associates, 1990) 


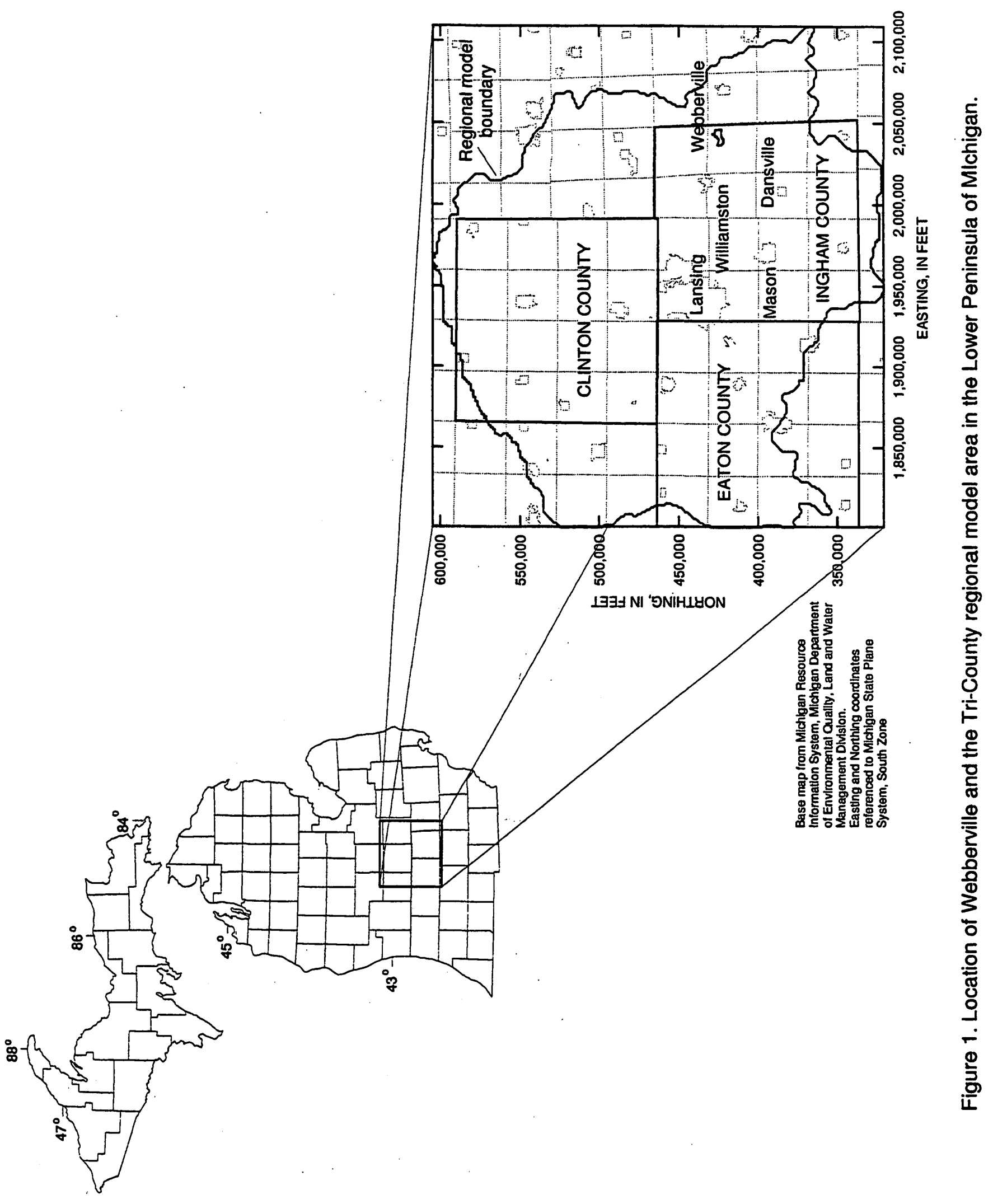



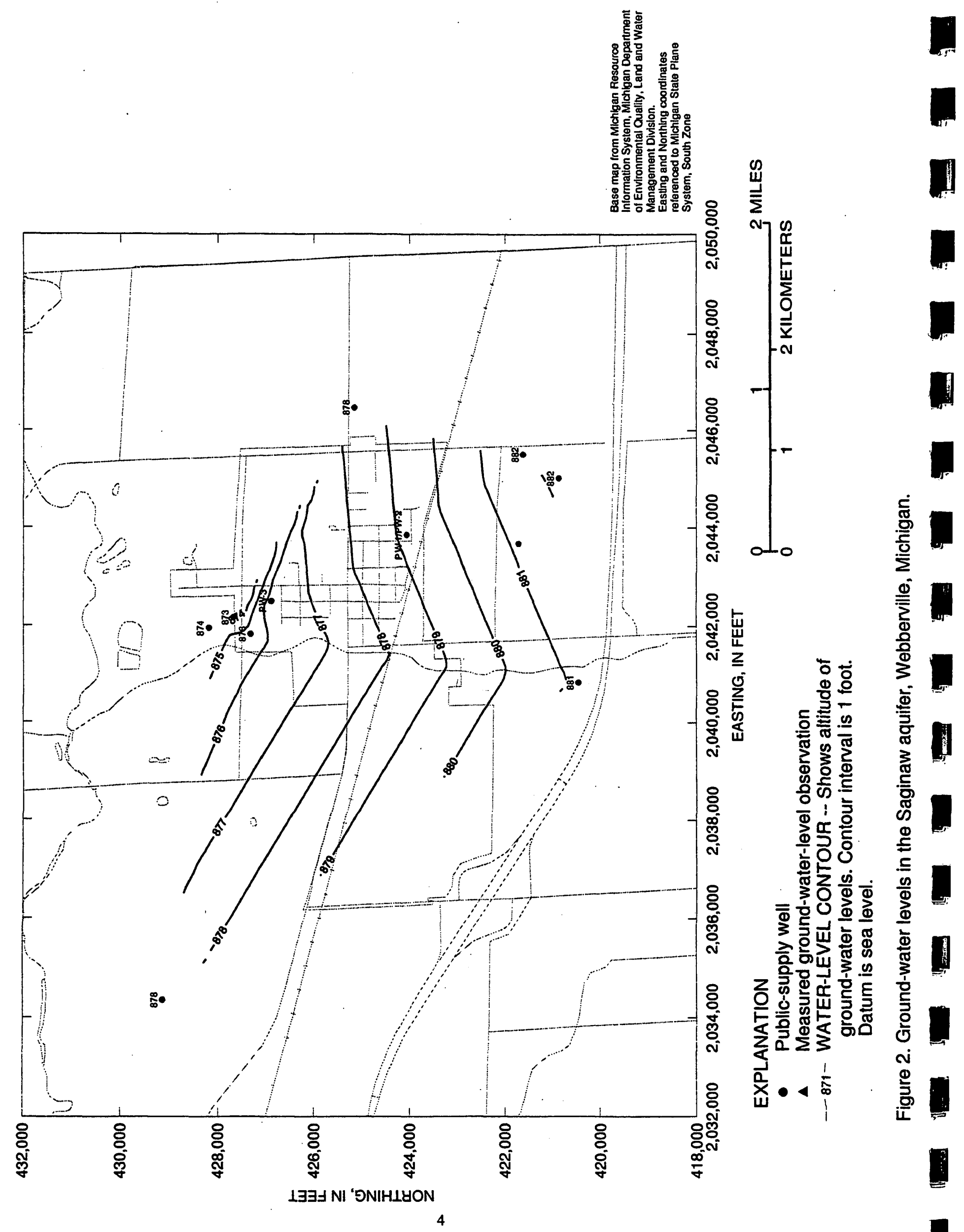
Table 1. Approximate location of Webberville's public-supply wells

(Northing and easting coordinates referenced to Michigan State Plane System, South Zone.)

\begin{tabular}{ccccc}
\hline Well & $\begin{array}{c}\text { Easting } \\
\text { (feet) }\end{array}$ & $\begin{array}{c}\text { Northing } \\
\text { (feet) }\end{array}$ & $\begin{array}{c}\text { Diameter } \\
\text { (inches) }\end{array}$ & $\begin{array}{c}\text { Depth } \\
\text { (feet) }\end{array}$ \\
\hline 1 & $2,043,853$ & 424,079 & 12 & 201 \\
2 & $2,043,856$ & 424,083 & 6 & 220 \\
3 & $2,042,510$ & 426,890 & 12 & 210 \\
\hline
\end{tabular}

from the village of Webberville's public-supply wells (table 1). Aquifer tests performed by C.J. Linck and Associates (1991 and 1992) at Well \#3 and a nearby test well indicate that the Saginaw aquifer has a transmissivity of about $3,800 \mathrm{gal} / \mathrm{day} / \mathrm{ft}$ or about $508 \mathrm{ft}^{2} / \mathrm{d}$.

\section{TELESCOPIC MESH REFINEMENT}

Telescopic mesh refinement allows the creation of a local embedded model based on boundary conditions and model parameters determined from a larger encompassing regional model (Buxton and Reilly, 1986; Miller and Voss, 1987; and Ward and others, 1987). Thus, representation of more detailed and localized flow conditions are possible within a portion of the regional model. A detailed model with finer grid spacing can be constructed for a small part of the aquifer system. The procedure is called telescopic mesh refinement because it can be applied repeatedly to construct successively smaller embedded models (Ward and others, 1987). Recently, Leake and Claar (1999) have developed three telescopic mesh refinement programs that work with MODFLOW-96 input data sets. MODTMR constructs MODFLOW data sets for a local model using MODFLOW data sets and simulation results from a regional model. TMRDIFF provides a means of comparing head or drawdown in the local model with head or drawdown in the corresponding area of the regional model. RIVGRID provides a means of constructing data sets for the River Package, Drain Package, General-Head Boundary Package, and Stream Package for regional and local models using grid-independent data specifying locations of these features (Leake and Claar, 1999).

Several factors must be considered before creating a local model from a regional model. The proposed boundaries of the local model must be entirely encompassed by the regional model. The regional model must reasonably represent hydrologic conditions in the area of local interest. Local model boundaries should include major sources and sinks near the area of interest; however, model boundaries should be distant from the area of interest so that the perimeter boundary conditions do not overly constrain the solution within the area of interest. The local model should incorporate more than a few cells of the regional model. Consistency with respect to model characteristics and parameters must be maintained between the local and regional models. Adjustments to parameters in the local model area should be incorporated in the regional model. Subsequently, the regional model should be rerun and new boundary conditions constructed for the local model. Finally, the water-budget components in the local model should be the same or nearly the same as those in the corresponding portion of the regional model (Leake and Claar, 1999).

For computer simulations, an updated version of the U.S. Geological Survey Modular Three-Dimensional Finite-Difference GroundWater Flow Model, MODFLOW-96, (McDonald and Harbaugh, 1988; Harbaugh and McDonald, 1996) was used. ZONEBUDGET (Harbaugh, 1990) was used to compute subregional water budgets for the local and 
regional models. The areas contributing water to the public-supply wells were delineated using a particle-tracking post-processor package for MODFLOW, known as MODPATH (Pollock, 1989).

\section{Regional model}

Holtschlag and others (1996) developed a three-dimensional steady-state ground-water flow model to describe the regional response of the Saginaw aquifer to ground-water withdrawals within the Tri-County region, which includes Ingham, Clinton, and Eaton Counties (fig. 1). The regional model simulates groundwater flow by dividing the Tri-County region into a grid containing 33,560 active cells in each of 2 layers. Each cell of the model grid represents a land-surface block $1,320 \mathrm{ft}$ on a side. The model has two layers: the upper layer represents flow within the glacial deposits and the lower layer represents flow in the Saginaw aquifer. Water enters the glacial deposits as recharge from precipitation and moves to streams or to the Saginaw aquifer in response to head gradients. Ground water exits the model at streams or wells. The Tri-County model was designed primarily to simulate ground-water flow within the Saginaw aquifer. Details on model development, parameters, and calibration are described by Holtschlag and others (1996).

The Tri-County regional model later was refined to better represent flow within the ninetownship area surrounding Lansing, Michigan (Luukkonen and others, 1997). Within the nine-township area, cell size was reduced from 1,320 to $660 \mathrm{ft}$ on a side. Streambed conductances were changed to reflect the revised cell sizes. All other model characteristics and parameters remained the same. Within the Webberville area, which is east of the ninetownship area, refined cell sizes are 660 by $1,320 \mathrm{ft}$ in the regional model.

\section{Local model}

Local model input data sets were constructed using MODTMR (Leake and Claar,
1999) and the following procedure: 1) simulate steady-state flow in the regional model, 2) construct local model data sets using MODTMR and the regional model input data sets and simulation results, 3) simulate flow in the local model, 4) compare local and regional model water budgets and ground-water levels using TMRDIFF, and 5) modify regional model to represent local variations and redo steps 1-4. Selection of boundaries for the local model considered the location of stresses, such as pumping wells, probable extent of contributing areas, and location of natural hydrologic features in the regional model. Simulated pumping wells in the regional model represent those of Williamston ( $5 \mathrm{mi}$ west of Webberville) and Dansville schools (10 $\mathrm{mi}$ southwest of Webberville, fig. 1). Simulated contributing areas to Webberville's public-supply wells using the regional model extend approximately $4.6 \mathrm{mi}$ south of Webberville. Webberville is about $8 \mathrm{mi}$ west of the eastern edge and $10 \mathrm{mi}$ north of no-flow boundaries in the regional model which represent areas where the sandstones of the Saginaw aquifer are thin or absent (fig. 1). Boundaries for the local model were selected to be $7 \mathrm{mi}$ north, $8 \mathrm{mi}$ east, $11 \mathrm{mi}$ south, and $9 \mathrm{mi}$ west of Webberville with the eastern local model boundary coinciding with the eastern regional model boundary. These boundaries are represented by no-flow conditions along the eastern and part of the southern edge and by specified flow conditions (Leake and Lilly, 1997) everywhere else. The local model grid for the Webberville area is oriented to the southern zone of the Michigan State Plane Coordinate System as displayed on USGS 7.5 minute topographic maps. The local model grid has a minimum northing of $1,994,220 \mathrm{ft}$; a maximum northing of $2,109,060 \mathrm{ft}$; a minimum easting of $363,120 \mathrm{ft}$; and a maximum easting of $466,080 \mathrm{ft}$ (fig. 3).

Given the selected local model characteristics and boundary locations, local model input data sets were created by use of MODTMR. The local model grid has 174 columns and 156 rows with a uniform grid spacing of $660 \mathrm{ft}$. All model characteristics were based on those in the corresponding area of the regional model except for well and river cell 


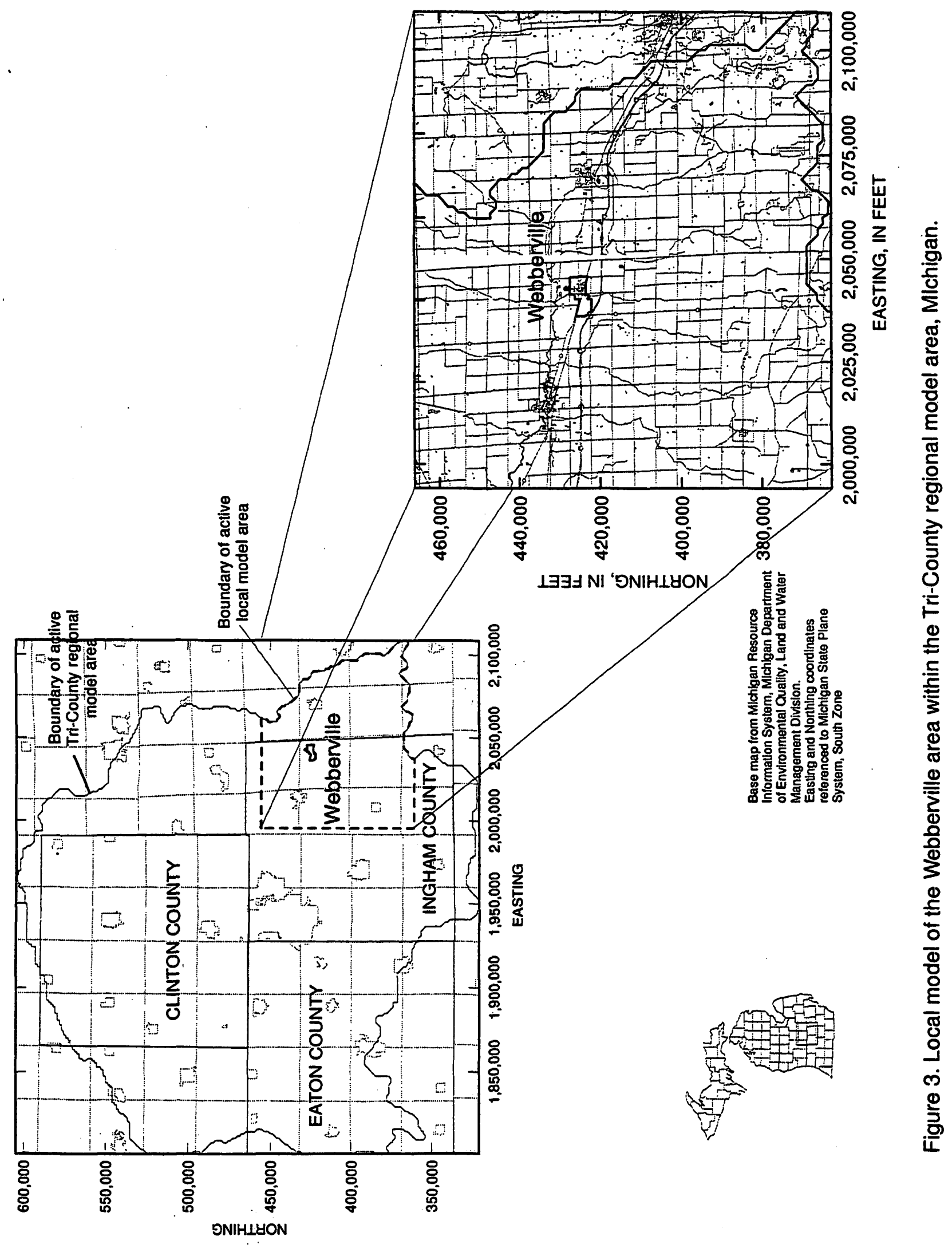


locations. Due to the smaller cell sizes in the local model, the locations of wells and rivers could be more accurately represented than in the regional model. Therefore, well and river cell locations were adjusted, if needed, to reflect their actual locations.

Results of local studies (C.J. Linck and Associates, 1990, 1991, and 1992) indicate that the bedrock surface in the regional model does not include local trends in the Webberville area. Other regional model characteristics and hydraulic parameters were within the ranges described for the Webberville area. The simulated regional bedrock surface was modified to show the north-south trending valley using information from local well logs and information collected by C.J. Linck and Associates (1990) (fig. 4). Hydraulic characteristics of the glacial deposits and the Saginaw aquifer are the same as in the corresponding area of the regional model (figs. 5 and 6). After incorporating the new bedrock surface information into the corresponding area of the regional model, new MODFLOW local model input data sets were created using MODTMR and local model budgets and ground-water levels compared to the corresponding area of the regional model.

\section{Comparison of regional and local models}

Simulated ground-water levels and model budgets from the local model were compared to those from the corresponding area of the regional model by use of TMRDIFF and ZONEBUDGET. The local model was calibrated primarily on the basis of comparison with the regional model and secondarily on the basis of comparison to measured water levels. Streambed conductances were modified to improve the calibration of the local model. Simulated ground-water levels in layer 1 (glacial aquifer) of the local model were within 0.9 to $10.4 \mathrm{ft}$ of those in layer 1 of the corresponding area of the regional model, whereas simulated ground-water levels in layer 2 (Saginaw aquifer) of the local model were within 0.5 to $3.5 \mathrm{ft}$ of those in layer 2 of the corre- sponding area of the regional model. The largest differences were along the western edge of the model in an area where the glacial deposits are thin. The average difference in simulated ground-water levels between the local and regional models was $0.4 \mathrm{ft}$ for layer 1 representing the glacial deposits and $0.3 \mathrm{ft}$ for layer 2 representing the Saginaw aquifer. Within the area representing Webberville's public-supply wells, simulated ground-water levels in both layers of the local model were within $1.5 \mathrm{ft}$ of those in the regional model. The differences in the area representing Webberville's public-supply wells can be attributed partially to the fact that the local model with its smaller cell spacing represents drawdowns induced by pumping in the Saginaw aquifer better than the regional model. Ground-water flow is primarily from south to north in the local model (figs. 7 and 8). Flows in the local model were in close agreement with flows in the corresponding portion of the regional model; differences were less than $0.1 \%$ (table 2 ).

As an additional calibration step, simulated ground-water levels in the local model were compared with water levels measured during this study and the previous Tri-County study (fig. 9). Because of the uncertainty associated with estimating a datum from a topographic map and with measuring depth to water in a recently developed well, measured water levels have an associated error of $+/-5 \mathrm{ft}$. Simulated ground-water levels were within $6 \mathrm{ft}$ of measured values obtained from local wells during this study; most of the simulated ground-water levels were within $8 \mathrm{ft}$ of historical values obtained from well logs.

\section{DELINEATION OF CONTRIBUTING} AREAS

The particle-tracking program MODPATH (Pollock, 1989) can be combined with MODFLOW-calculated flow in each cell to determine the land surface (contributing area) and the subsurface (zone-of-transport area) areas contributing water to public-supply wells. Particle tracking describes the advective 
Table 2. Comparison of regional and local model budgets

\begin{tabular}{lccc}
\hline Budget component & $\begin{array}{c}\text { Part of regional model } \\
\text { corresponding to the } \\
\text { Webbervilie area } \\
\text { (feet cubed per day) }\end{array}$ & $\begin{array}{c}\text { Local model of } \\
\text { Webberville area } \\
\text { (feet cubed per } \\
\text { day) }\end{array}$ & difference \\
\hline IN - Flow through boundary & 144,830 & 144,680 & 0.001 \\
River & 861,220 & 859,790 & 0.002 \\
Recharge & $12,828,000$ & $12,827,820$ & 0.0 \\
OUT - Flow through boundary & $1,036,900$ & $1,038,150$ & -0.001 \\
Wells & 63,208 & 63,208 & 0.0 \\
River & $12,734,000$ & $12,730,960$ & 0.0002 \\
Percent discrepancy & .0 & .0 & \\
\hline
\end{tabular}

movement of ground water and does not incorporate the effects of diffusion, dispersion, and degradation. Therefore, particle tracking is not intended as a substitute for modeling the transport of dissolved chemicals in the ground-water system. An estimated porosity of 15 percent was used for both layers (Holtschlag and others, 1996).

Ground-water flow paths, and thus particle-tracking results, depend, in part, on the stresses to the system. Different pumping rates or locations will change the ground-water flow solution in the modeled area and result in different contributing and zone of transport areas to the pumping wells. Multiple pumping scenarios were investigated by using backward particle tracking to estimate the effect on the shape and extent of the contributing areas in Webberville and the surrounding township and provide an estimate of the maximum potential contributing area. In anticipation of future water-supply demands, three proposed well locations were provided by Webberville for analysis, in addition to the 3 public-supply wells. Two of the public-supply wells were simulated in the same cell. In each simulation, 400 hypothetical particles were placed on each of the five active faces of each cell containing a pumped well, for a total of 2,000 particles per well.
Ground-water withdrawals totaled $0.13 \mathrm{mgd}$ for Webberville's existing public-supply wells; withdrawals of $0.07 \mathrm{mgd}$ were simulated for each of the proposed well locations. Modeled scenarios included simulation of pumping at the existing public-supply wells with each of the proposed wells alone and together (figs. 10-14). An additional scenario simulated pumping at the proposed well locations while the existing wells were idle (fig. 15). Ten-year and 40-year time-of-travel areas were delineated for each scenario (table 3). The minimum travel time from the top cell face of layer 1 to each well was greater than 10 years in all scenarios; therefore, there are no 10 -year contributing areas.

Zone-of-transport areas for the two existing public-supply wells merge. The shape and extent of these areas do not change when pumping at proposed wells at locations $A$ and $C$ is simulated. Contributing and zone-of-transport areas for proposed wells at locations $A$ and $C$ are separate from those for the existing publicsupply wells; however, the contributing and zone-of-transport areas for the existing publicsupply wells merge with those for the proposed well at location B. Ten-year zone-of-transport areas for proposed wells at locations $A, B$, and $C$ are the same whether the existing wells are simulated as pumping or not; however, the 

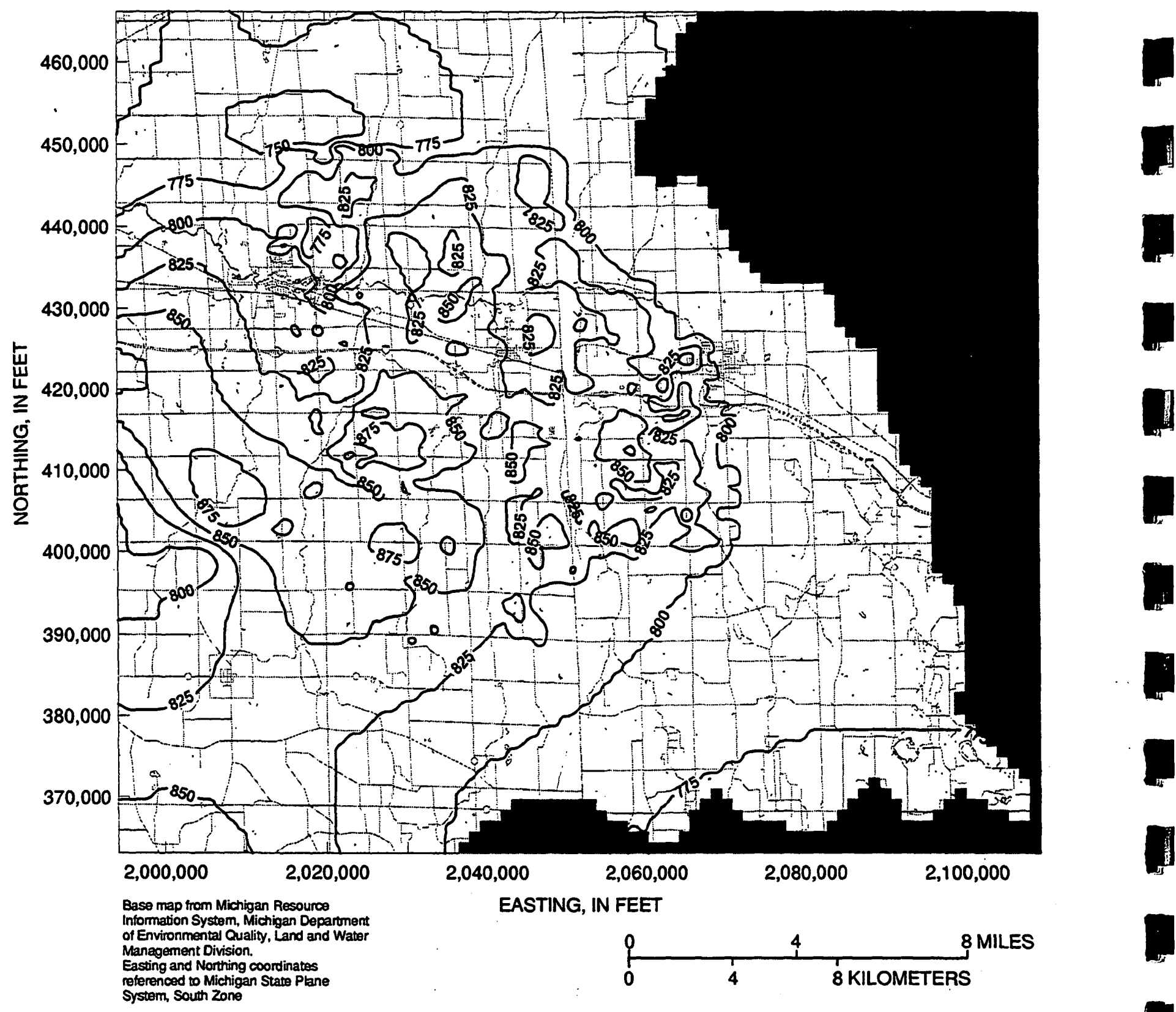


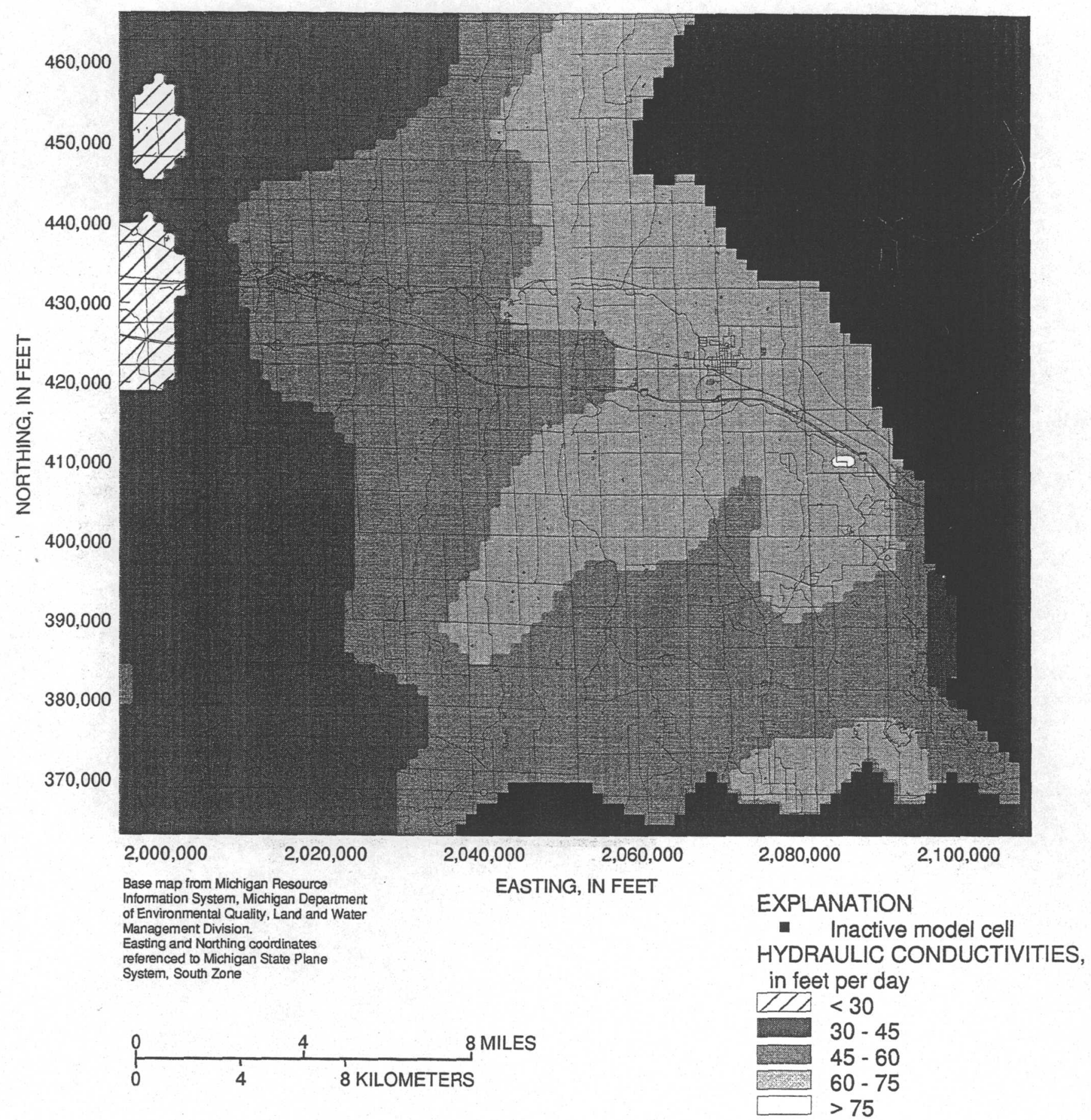

Figure 5. Estimated hydraulic conductivity of the upper layer, Webberville, Michigan. 


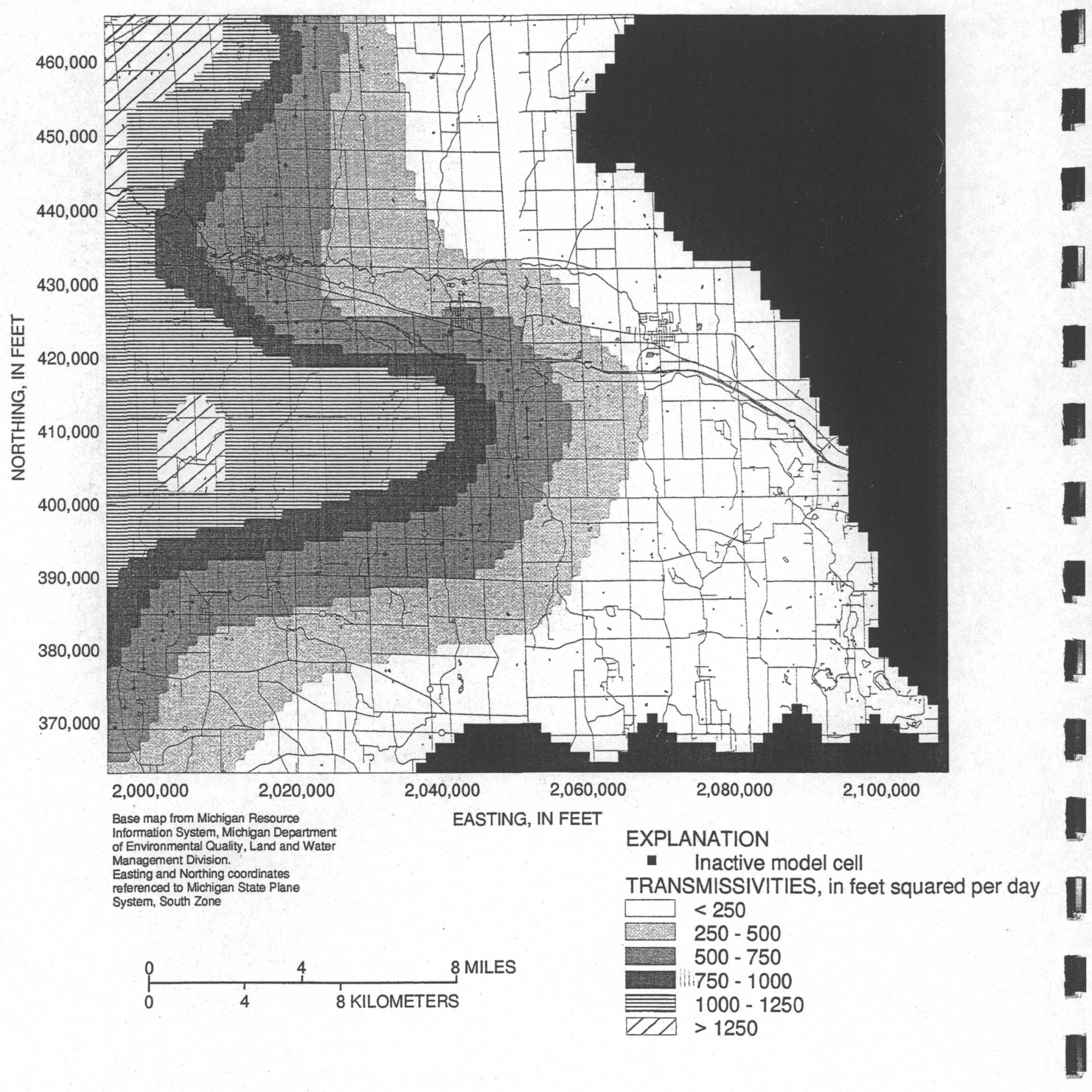

Figure 6. Estimated transmissivity of the lower layer, Webberville, Michigan. 


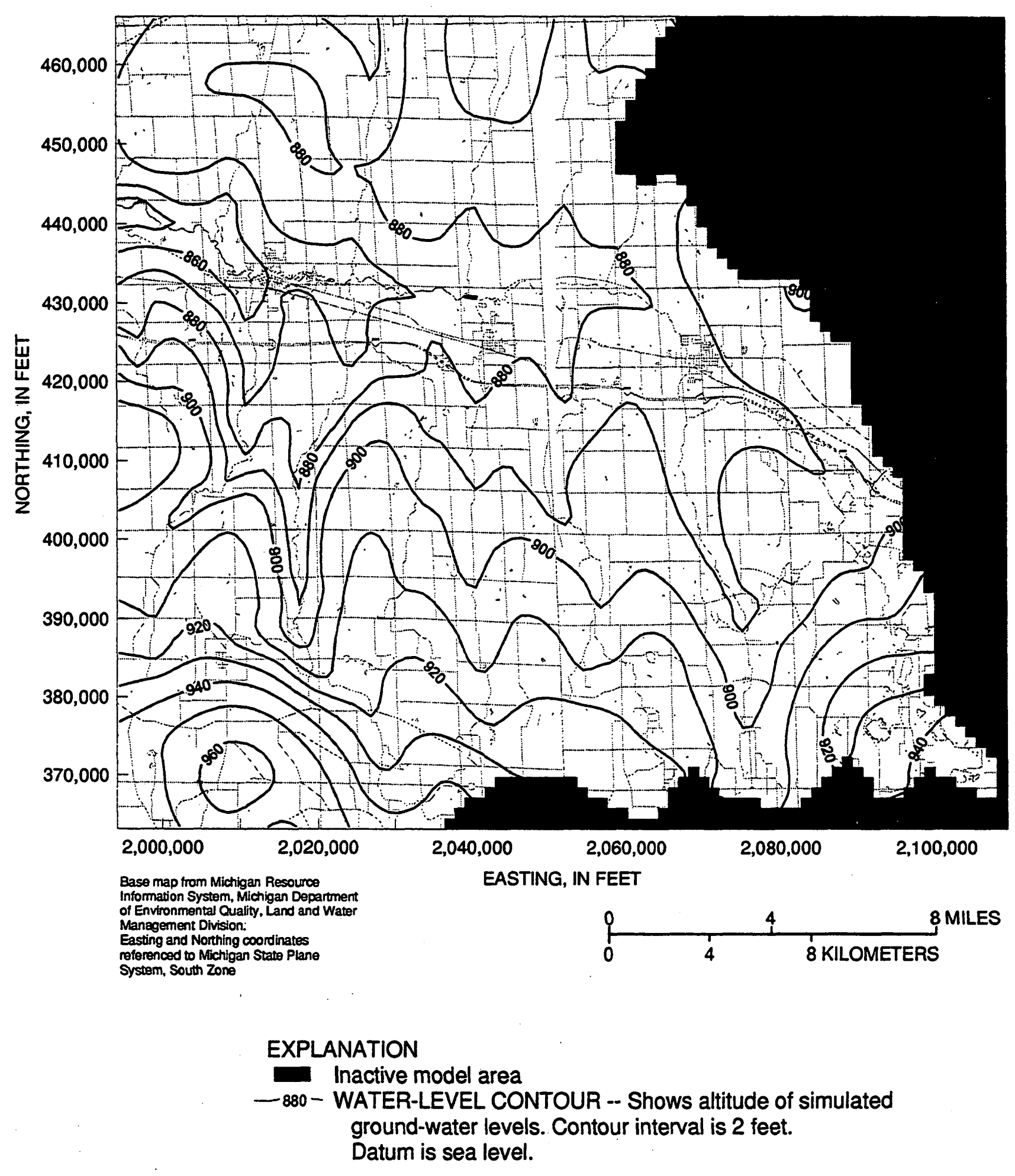

Figure 7. Simulated head in the upper aquifer, Webberville, Michigan. 


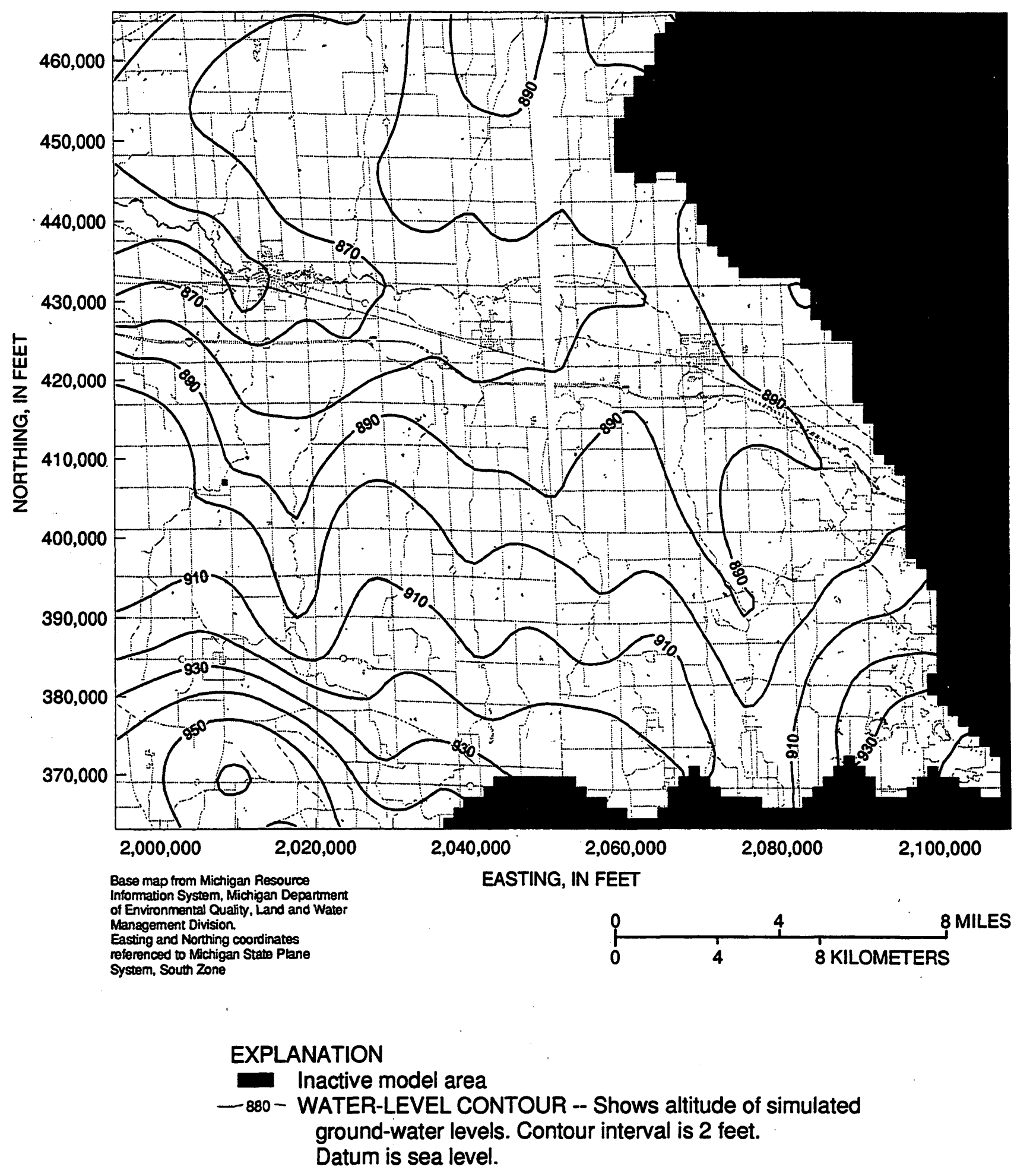

Figure 8. Simulated head in the lower aquifer, Webberville, Michigan. 


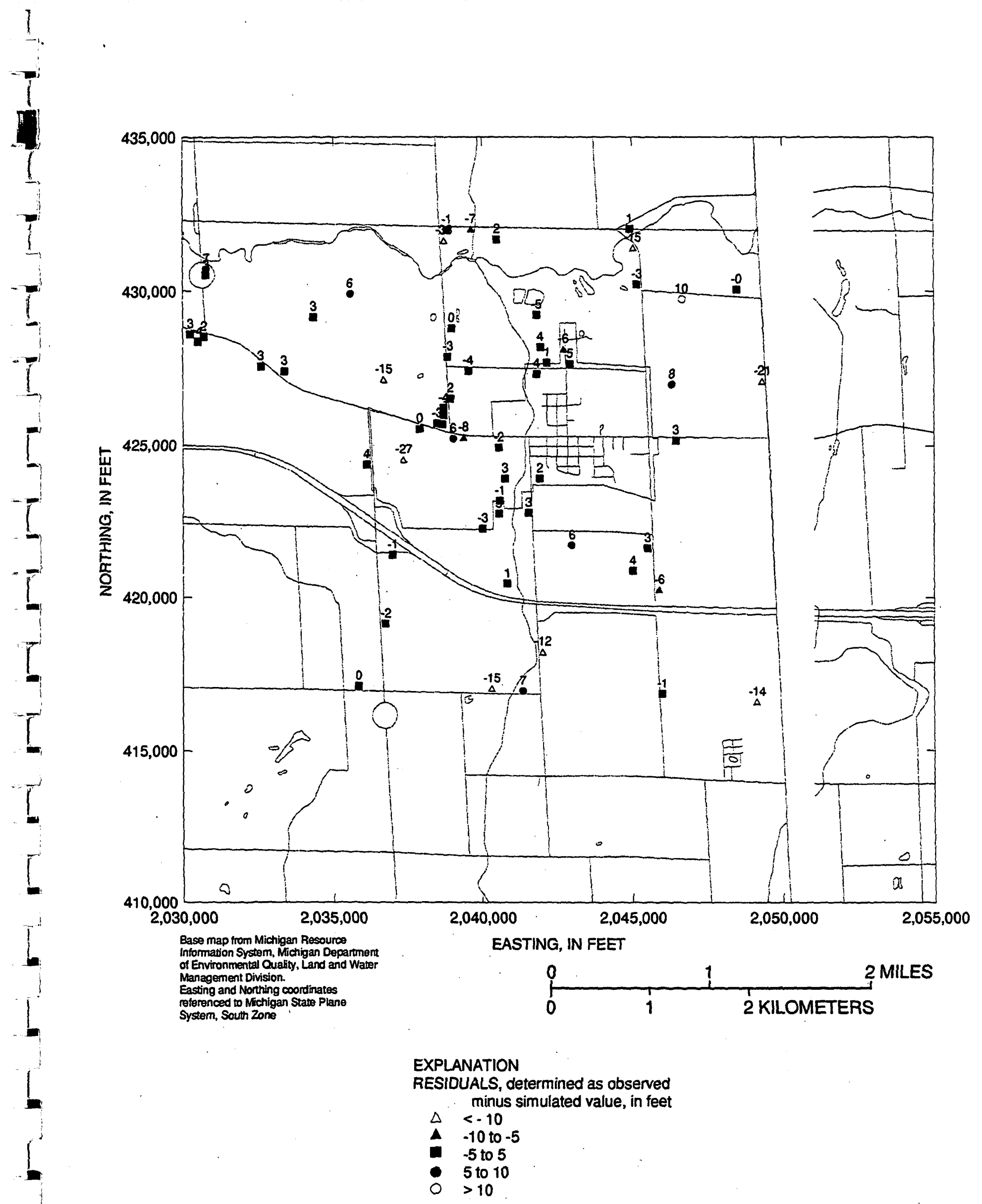

Figure 9. Distribution of water-level residuals in the Saginaw aquifer, Webberville, Michigan 


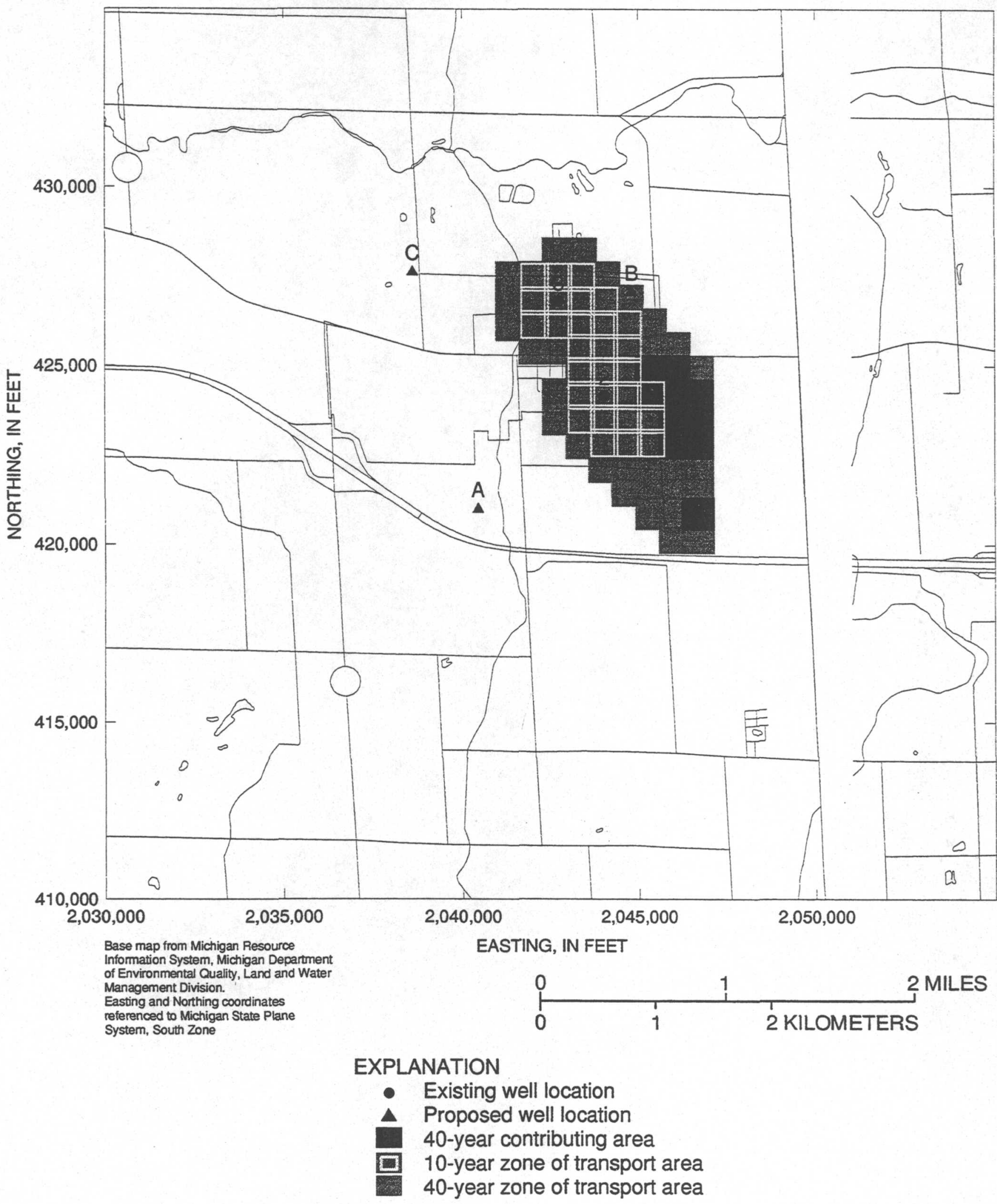

Figure 10. Contributing and zone-of-transport areas for existing wells, Webberville, Michigan. 


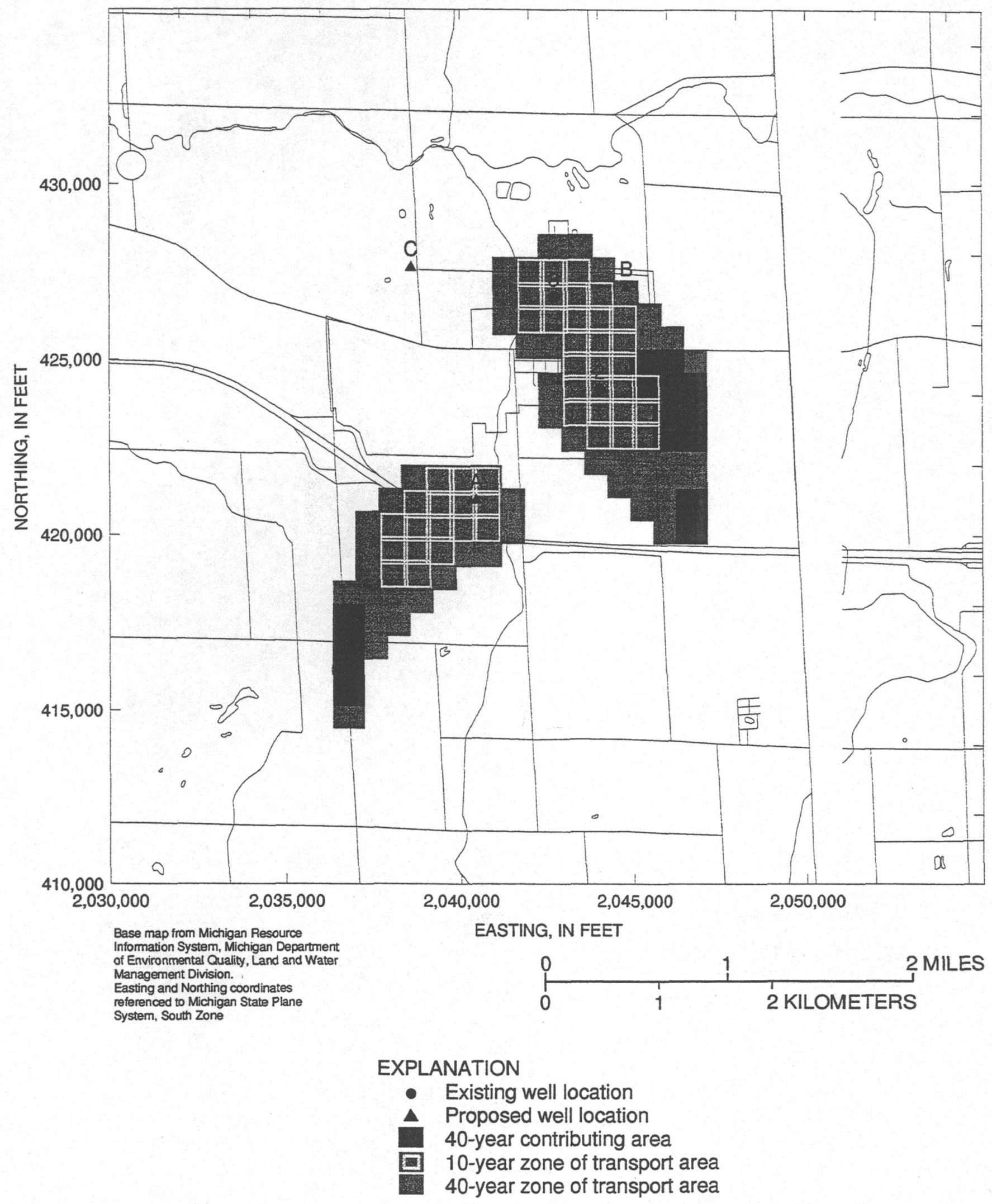

Figure 11. Contributing and zorie-of-transport areas for existing and proposed location A wells, Webberville, Michigan. 


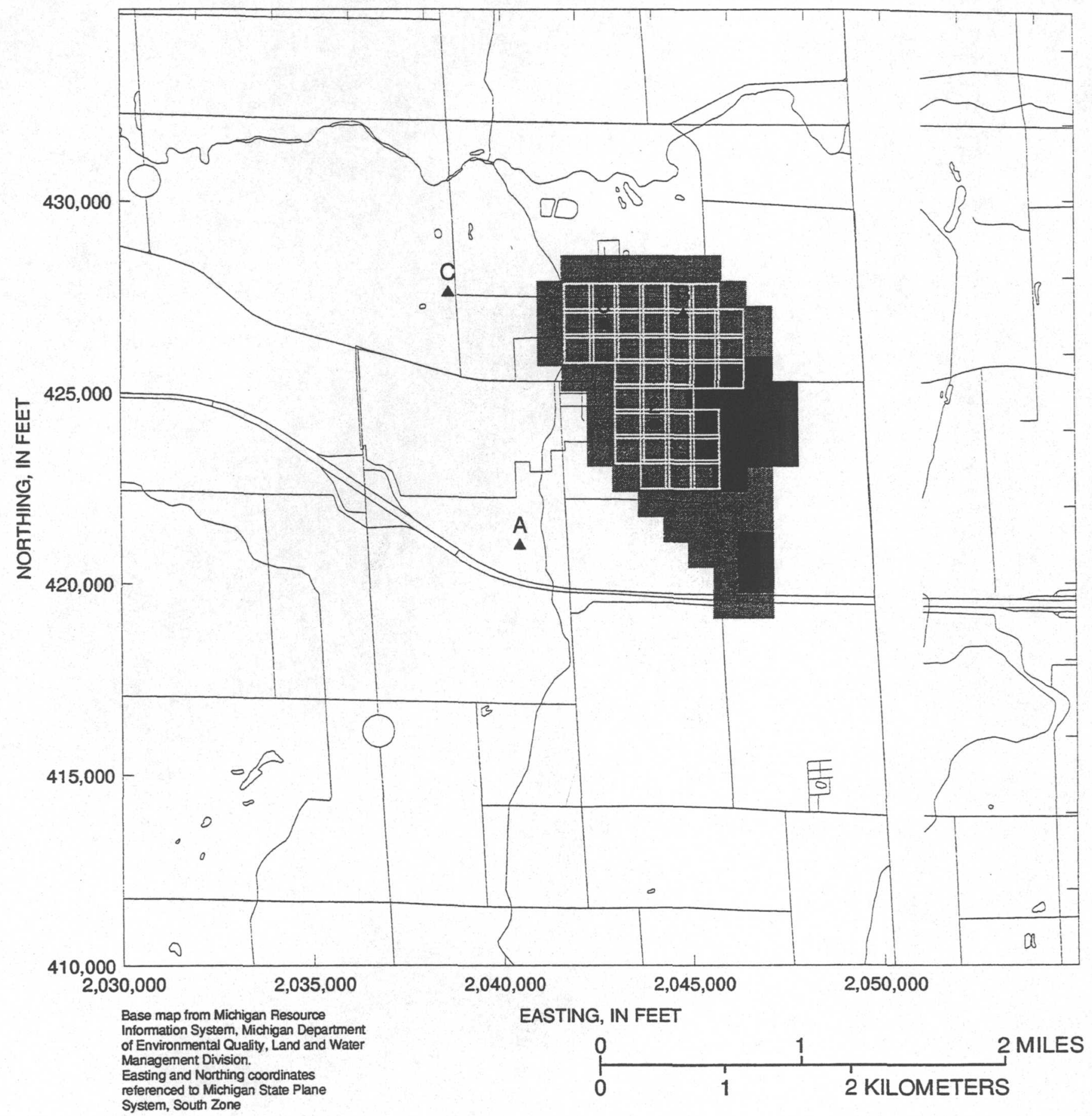

EXPLANATION

- Existing well location

- Proposed well location

40-year contributing area

10-year zone of transport area

40-year zone of transport area

Figure 12. Contributing and zone-of-transport areas for existing and proposed location $B$ wells, Webberville, Michigan 


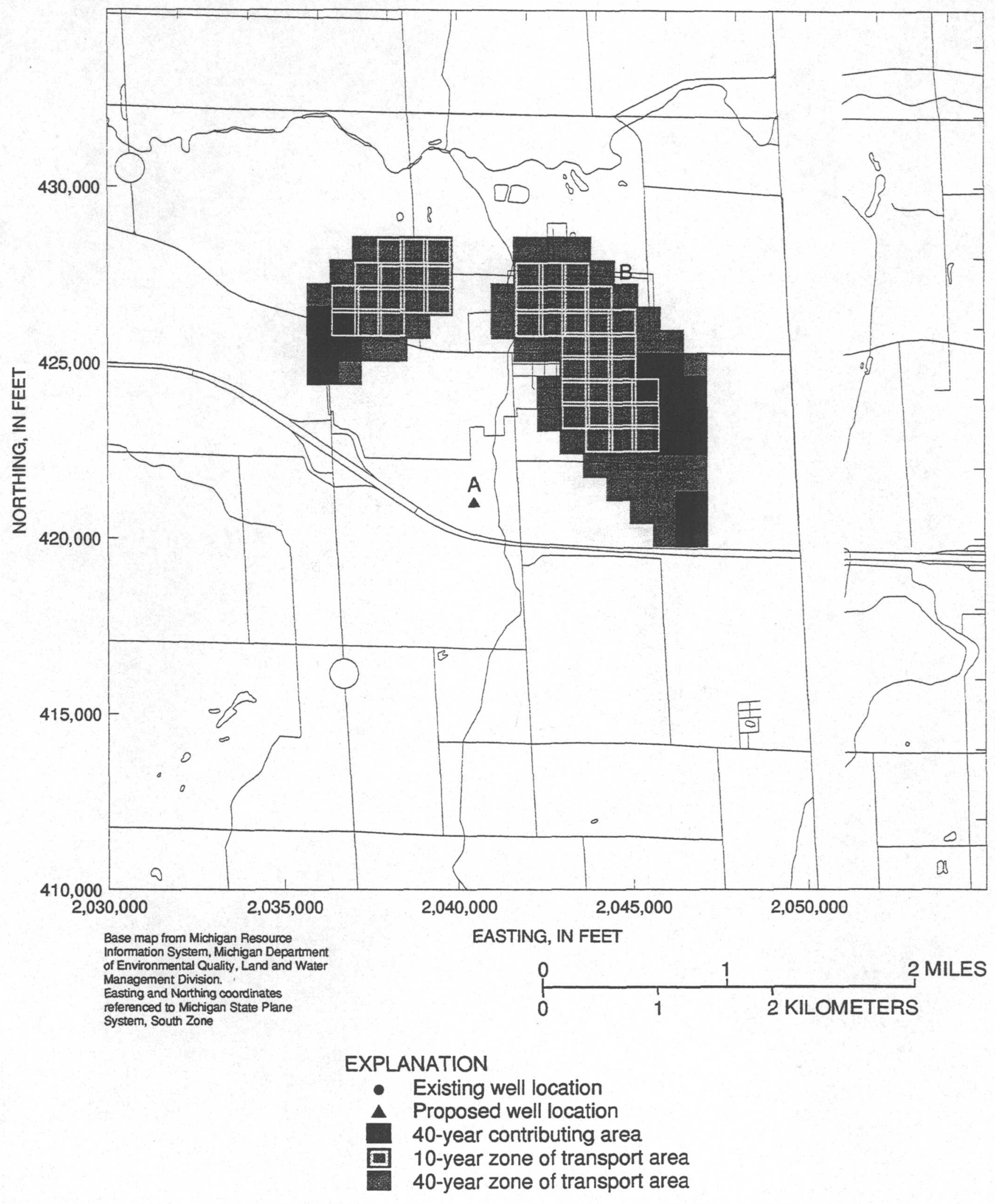

Figure 13. Contributing and zone-of-transport areas for existing and proposed location C wells, Webberville, Michigan. 

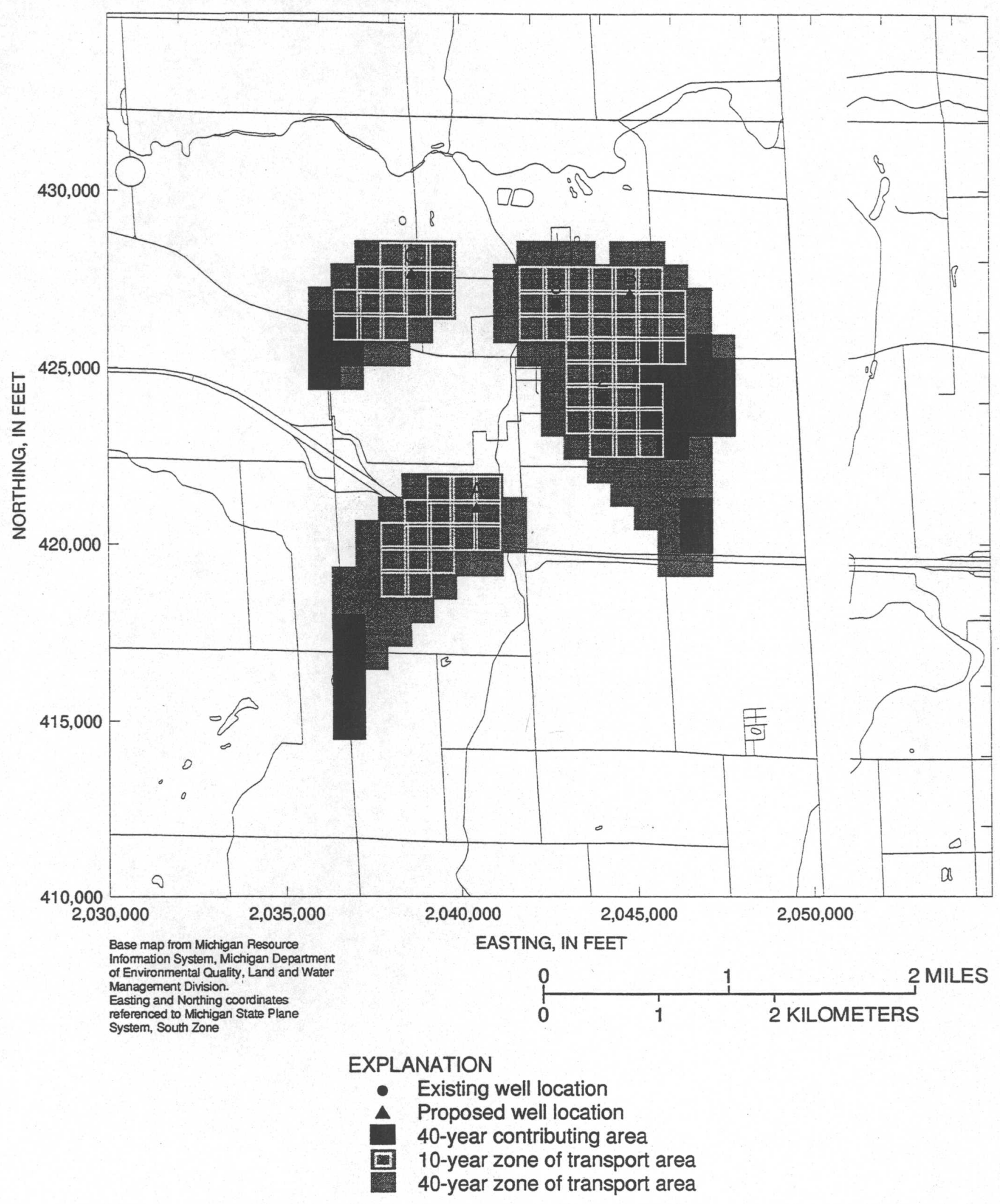

Figure 14. Contributing and zone-of-transport areas for existing and proposed location $\mathrm{A}, \mathrm{B}$, and $\mathrm{C}$ wells, Webberville, Michigan. 


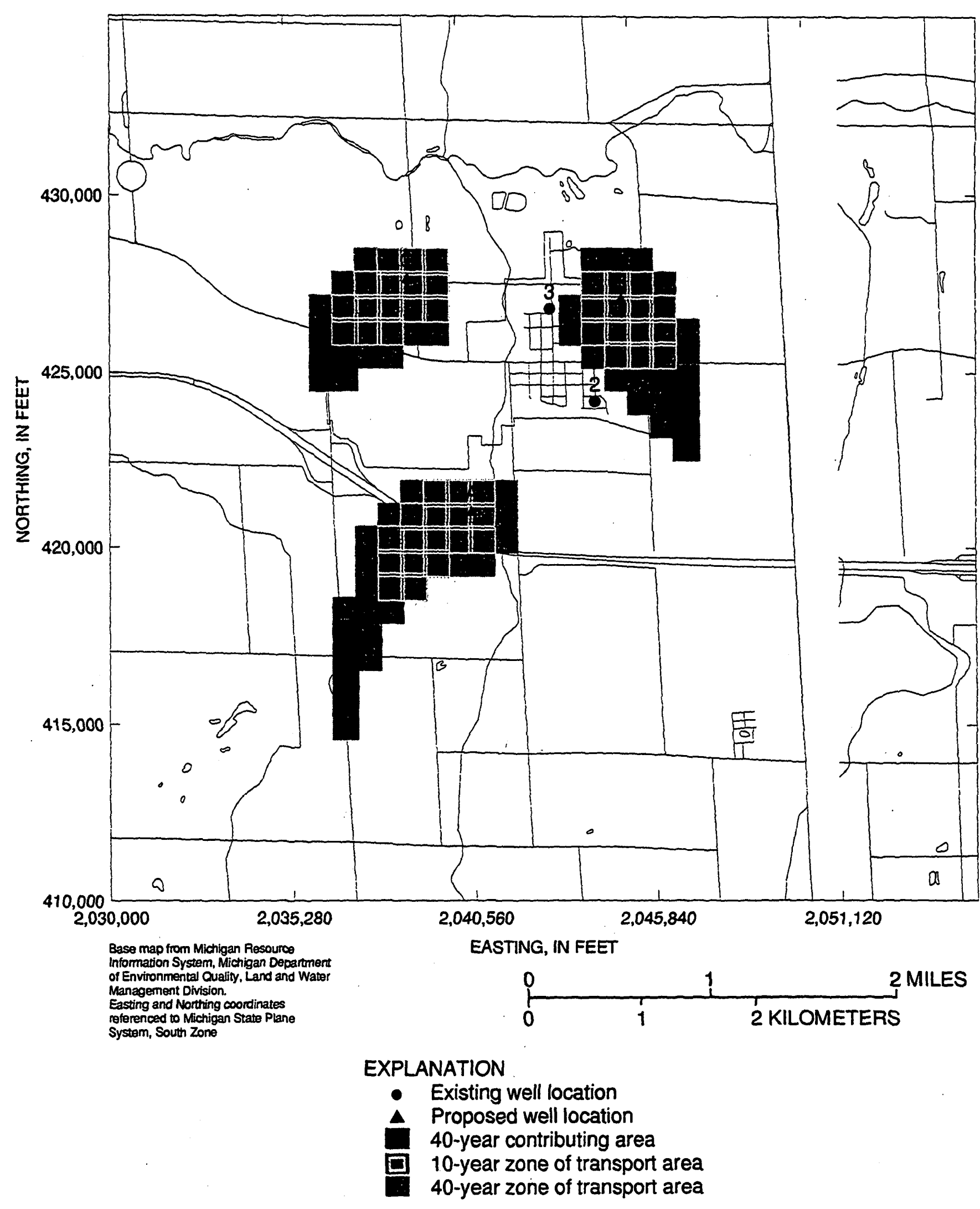

Figure 15. Contributing and zone-of-transport areas for proposed location $A, B$, and $C$ wells, Webberville, Michigan 
Table 3. Contributing and zone-of-transport areas for pumping well scenarios

\begin{tabular}{lcccc}
\hline Scenario & $\begin{array}{c}\text { Pumping rates } \\
\text { (million } \\
\text { gallons per } \\
\text { day) }\end{array}$ & $\begin{array}{c}\text { 10-year } \\
\text { zone-of-transport } \\
\text { areas } \\
\text { (square miles) }\end{array}$ & $\begin{array}{c}\text { 40-year } \\
\text { contributing areas } \\
\text { (square miles) }\end{array}$ & $\begin{array}{c}\text { 40-year } \\
\text { zone-of-transport } \\
\text { areas } \\
\text { (square miles) }\end{array}$ \\
\hline Existing wells & 0.13 & 0.5 & 0.2 & 1.0 \\
Existing wells + location A & 20 & .7 & .2 & 1.7 \\
Existing wells + location B & .20 & .6 & .3 & 1.3 \\
Existing wells + location C & .20 & .7 & .3 & 1.5 \\
Existing wells + locations & .34 & 1.1 & .4 & 2.4 \\
A, B, and C & .21 & .7 & .2 & 1.5 \\
Locations A, B, and C only & .21 & & & \\
\hline
\end{tabular}

40-year contributing and zone-of-transport areas change shape and extent depending on whether the existing wells are simulated as pumping or not.

The 10-year zone-of-transport areas for Webberville's existing public-supply wells encompass 29 model cells, or a total of about $0.5 \mathrm{mi}^{2}$, and consist of most of the central village area. The 40-year contributing areas for Webberville's public-supply wells encompass 10 model cells, or a total of about $0.2 \mathrm{mi}^{2}$, and consist of an area south and east of the southernmost public-supply well. The 40-year zoneof-transport area for Webberville's existing public-supply wells encompasses 67 model cells, or a total of about $1.0 \mathrm{mi}^{2}$, and consists of the area between and around the publicsupply wells.

\section{Model limitations}

The local ground-water flow model was developed from the Tri-County regional model to simulate the steady-state response of the Saginaw aquifer flow system in the Webberville area to withdrawals from the public-supply wells. The accuracy of the local model, including hydraulic parameters and boundary conditions, is dependent on the accuracy of the regional model from which it was developed and the local information collected from previous studies. Only the bedrock surface was updated to reflect more local information. Further improvement in modeling hydrogeologic conditions within the Webberville area could be achieved by the collection and incorporation of more detailed information.

Hydraulic properties in the aquifers were assumed to be isotropic. Vertical variations in aquifer properties within layers and any variations in head or flow within the aquifers are not represented in the model. Each grid cell represents the average hydrologic and hydraulic properties in the volume of aquifer represented by the cell; thus, any variations in properties within the volume represented by the grid cell cannot be represented by the model. Local flows over distances smaller than the dimensions of the grid cell likewise cannot be represented accurately.

Recharge was assumed to follow regional patterns found in the Lower Peninsula of Michigan (Holtschlag, 1994); thus, local variations in recharge rates, such as those associated with impermeable surfaces or differences in surficial materials, are not represented in the model. Simulated well pumpages are assumed 
to come from the centers of the grid cells. Furthermore, within the model, wells are assumed to fully penetrate the aquifer and flow is horizontal. Thus the model-simulated water surface is flatter than the actual surface (fig. 16); vertical gradients and the actual pumping intervals within a layer are not represented. Small pumpages from domestic wells which are outside the village limits of Webberville were not included due to the difficulty in obtaining reliable data and the limitations in representing small-scale flow systems. The accuracy of layer surfaces and hydraulic conductivity estimates is limited by the available data at well and boring locations. Additional control and accuracy could be achieved by availability of more data points.

Model simulations are restricted to steady-state conditions. All stresses within and inputs to the system, including well pumpages and recharge, remain constant throughout the simulation. No net gain or loss of flow is simulated in the system and no changes in storage occur. This model in its current form cannot be used to simulate transient-flow conditions.

The accuracy of particle-tracking simulations is limited by the accuracy of the numerical model on which the simulations are based, the estimates of the effective porosity of the flow system, and the approximation of the cell flow velocities to the local ground-water flow velocities. Additionally the particle-tracking program considers ground-water flow by advection only. If the effects of dispersion were included, the contributing areas could be larger. The shape and extent of the contributing and zone-of-transport areas also is dependent on the choice of hydraulic parameters such as transmissivity and riverbed conductance and on the pumping rates of the individual wells. After modification of some of these parameters a similar ground-water-flow solution was obtained; however, the resulting 10-year zoneof-transport to the existing public-supply wells is larger (fig. 17). Because the model does not specifically describe flow through fractures, ground-water flow and travel times in areas where fractures exist may not be represented accurately.

\section{SUMMARY}

The village of Webberville, Michigan, needs to determine the areas that contribute water to the public-supply wells for their Wellhead Protection Program. However, local variations in the surface of the Saginaw Formation within the Webberville area that are not represented in an existing regional ground-waterflow model, as well as the grid spacing of the regional model, prevent using the regional model to represent local flow systems. More detail was needed to adequately represent ground-water flow conditions within the Webberville area and determine the areas that contribute water to the public-supply wells.

Telescopic mesh refinement was utilized to create a local model for the Webberville area using the existing regional steady-state ground water flow model developed for the TriCounty region by the following steps: 1) simulate steady-state flow in the regional model, 2) construct local model data sets using the MODTMR program and the regional model input data sets and simulation results, 3) simulate flow in the local model, 4) compare local and regional model water budgets and groundwater levels using the TMRDIFF program, and 5) modify regional model to represent local variations and redo steps 1-4. River cell locations and conductances were adjusted to improve agreement between model budget components and ground-water levels. Groundwater model budget components for the local model and the corresponding portion of the regional model were within 0.3 percent. Simulated ground-water levels agreed with measured water levels collected during this study and during the previous Tri-County study with the majority of differences less than 8 feet.

The effect of the number and location of pumping wells on the shape and extent of contributing and zone-of-transport areas was investigated using particle tracking under multiple pumping scenarios. The effect of changes in some model parameters on the shape and extent of the 10-year zone-of-transport areas to the existing public-supply wells also was investigated. Contributing and zone-of-transport areas were delineated for various combi- 


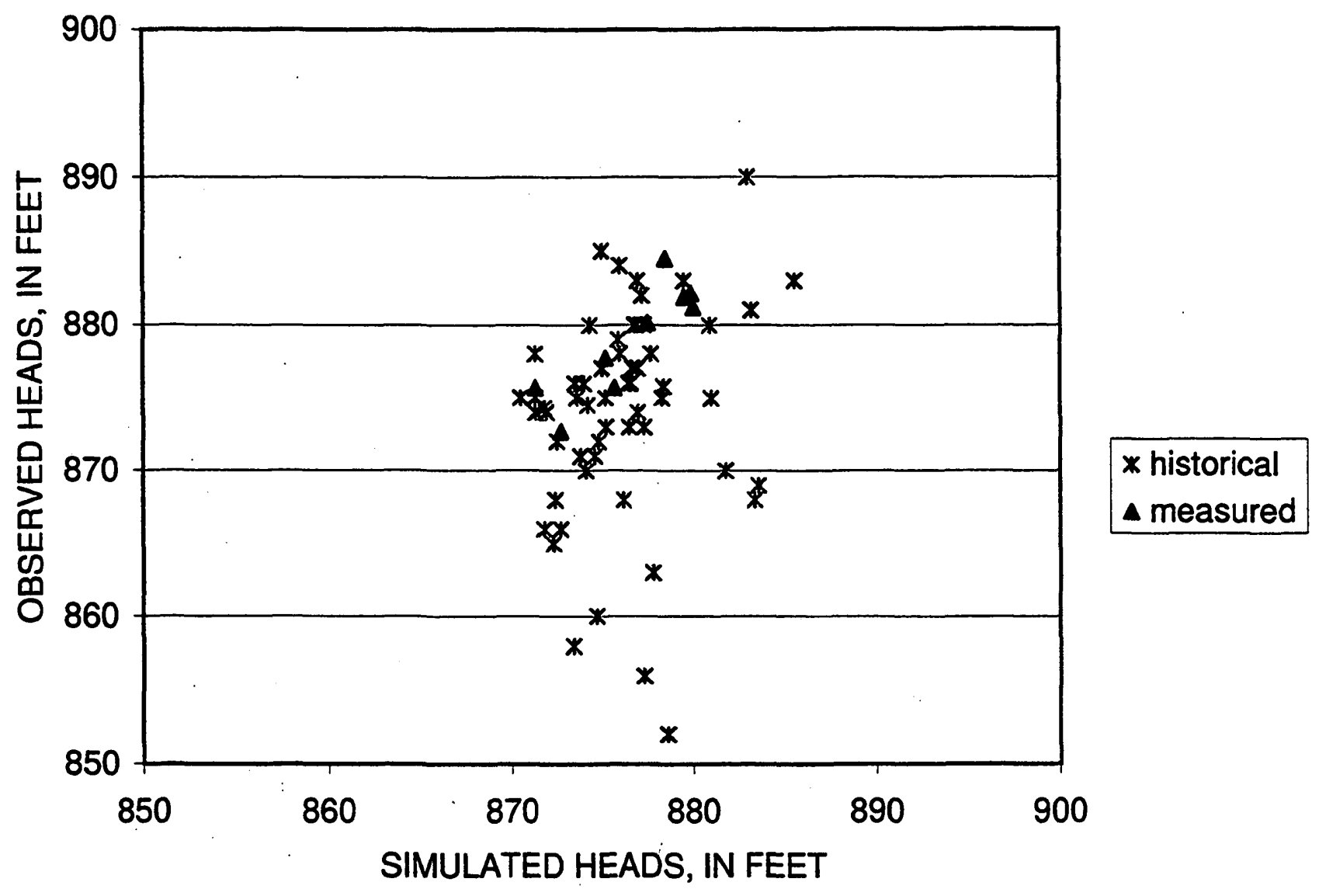

Figure 16. Relation between simulated and observed heads in the Saginaw aquifer. 


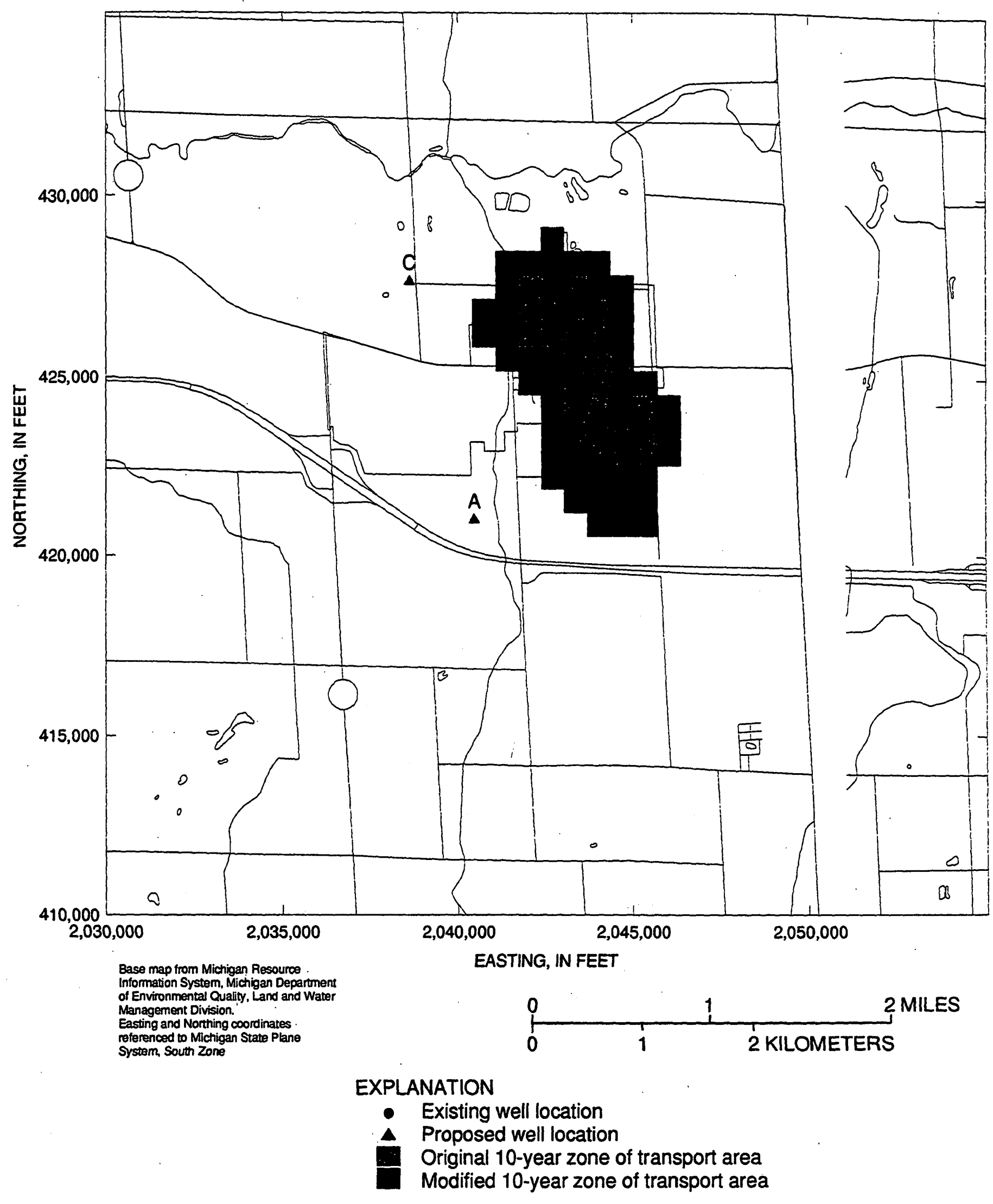

Figure 17. Extent of 10-year zone-of-transport areas for existing wells using modified model parameters, Webberville, Michigan. 
nations of Webberville's existing public-supply wells and three proposed future well locations. The minimum travel time from the top cell face of layer 1 of the model was greater than 10 years for all scenarios; therefore, there are no 10-year contributing areas. Ten-year zoneof-transport, as well as 40-year contributing and zone-of-transport areas generally consist of disconnected areas near each simulated well. The 10-year zone-of-transport areas for the existing public-supply wells were larger with changes in the bedrock surface and riverbed conductances, recharge, and porosity.

\section{REFERENCES}

Anderson, M.P., and Woessner, W.W, 1992. Applied groundwater modeling, simulation of flow and advective transport: San Diego, Academic Press, Inc., 381 p.

Buxton, H. and Reilly, T.E., 1986. A technique for analysis of ground-water systems of regional and subregional scales applied to Long Island, New York: U.S. Geological Survey Water-Supply Paper 2310, p. 129-142.

Cooley, R.L., and Naff, R.L., 1990. Regression modeling of ground-water flow: U.S. Geological Survey Techniques of Water Resources Investigations, Book 3, Chap. B4, 232 p.

C.J. Linck and Associates, 1990. Hydrogeologic investigation of the Webberville area for the village of Webberville, Michigan, variously paged.

C.J. Linck and Associates, 1991. Aquifer performance test on TW no. 91-A, Summit Street site, for the village of Webberville, Michigan, variously paged.

C.J. Linck and Associates, 1992. Evaluation of production well no. 3, Summit Street site, for the village of Webberville, Michigan, variously paged.
Freeze, R.A., and Cherry, J.A., 1979. Groundwater: Englewood Cliffs, New Jersey: Prentice Hall, Inc., 604 p.

Harbaugh, A.W., 1990. A computer program for calculating subregional water budgets using results from the U.S. Geological Survey Modular three-dimensional finitedifference ground-water flow model: U.S. Geological Survey Open-File Report 90-392, $46 \mathrm{p}$.

Harbaugh, A.W., and McDonald, M.G, 1996. User's documentation for MODFLOW96, an update to the U.S. Geological Survey modular finite-difference groundwater flow model: U.S. Geological Survey Open-File Report 96-485, 56 p.

Holtschlag, D.J., 1994. A generalized estimate of ground-water recharge rates in the lower peninsula of Michigan: U.S. Geological Survey Water Supply Paper 2437, $81 \mathrm{p}$.

Holtschlag, D.J., Luukkonen, C.L., and Nicholas, J.R., 1996. Simulation of groundwater flow in the Saginaw aquifer, Clinton, Eaton, and Ingham Counties, Michigan: U.S. Geological Survey Water Supply Paper 2480, 49 p.

Leake, S.A. and Claar, D.V., 1999. Procedures and computer programs for telescopic mesh refinement using MODFLOW: U.S. Geological Survey Open-File Report 99-238, $71 \mathrm{p}$.

Leake, S.A., and Lilly, M.R., 1997. Documentation of a computer program (FHB1) for assignment of transient specified-flow and specified-head boundaries in applications of the Modular Finite-Difference Ground-Water Flow Model (MODFLOW): U.S. Geological Survey OpenFile Report 97-571, 50 p.

Luukkonen, C.L., Grannemann, N.R., and Holtschlag, D.J., 1997. Ground-water flow in the Saginaw aquifer in the vicinity of the North Lansing well field, Lansing, 
